\title{
Hypoxia leads to significant changes in alternative splicing and elevated expression of CLK splice factor kinases in PC3 prostate cancer cells
}

Elizabeth Bowler ${ }^{1}$, Sean Porazinski ${ }^{1}$, Simon Uzor ${ }^{1}$, Philippe Thibault², Mathieu Durand ${ }^{2}$, Elvy Lapointe², Kasper M. A. Rouschop ${ }^{3}$, John Hancock ${ }^{1}$, lan Wilson ${ }^{1}$ and Michael Ladomery ${ }^{1 *}$

\begin{abstract}
Background: Mounting evidence suggests that one of the ways that cells adapt to hypoxia is through alternative splicing. The aim of this study was firstly to examine the effect of hypoxia on the alternative splicing of cancer associated genes using the prostate cancer cell line PC3 as a model. Secondly, the effect of hypoxia on the expression of several regulators of splicing was examined.

Methods: PC3 cells were grown in 1\% oxygen in a hypoxic chamber for $48 \mathrm{~h}$, RNA extracted and sent for high throughput PCR analysis at the RNomics platform at the University of Sherbrooke, Canada. Genes whose exon inclusion rate PSI $(\psi)$ changed significantly were identified, and their altered exon inclusion rates verified by RT-PCR in three cell lines. The expression of splice factors and splice factor kinases in response to hypoxia was examined by qPCR and western blotting. The splice factor kinase CLK1 was inhibited with the benzothiazole TG003.

Results: In PC3 cells the exon inclusion rate PSI $(\psi)$ was seen to change by $>25 \%$ in 12 cancer-associated genes; $M B P$, APAF1, PUF60, SYNE2, CDC42BPA, FGFR10P, BTN2A2, UTRN, RAP1GDS1, PTPN13, TTC23 and CASP9 (caspase 9). The expression of the splice factors SRSF1, SRSF2, SRSF3, SAM68, HuR, hnRNPA1, and of the splice factor kinases SRPK1 and CLK1 increased significantly in hypoxia. We also observed that the splice factor kinase CLK3, but not CLK2 and CLK4, was also induced in hypoxic DU145 prostate, HT29 colon and MCF7 breast cancer cell lines. Lastly, we show that the inhibition of CLK1 in PC3 cells with the benzothiazole TG003 increased expression of the anti-apoptotic isoform caspase 9b.

Conclusions: Significant changes in alternative splicing of cancer associated genes occur in prostate cancer cells in hypoxic conditions. The expression of several splice factors and splice factor kinases increases during hypoxia, in particular the Cdclike splice factor kinases CLK1 and CLK3. We suggest that in hypoxia the elevated expression of these regulators of splicing helps cells adapt through alternative splicing of key cancer-associated genes. We suggest that the CLK splice factor kinases could be targeted in cancers in which hypoxia contributes to resistance to therapy.
\end{abstract}

Keywords: Hypoxia, Alternative splicing, Prostate cancer, Apoptosis, Splice factors, Splice factor kinases, CLK1, CLK3, TG003

\footnotetext{
* Correspondence: Michael.Ladomery@uwe.ac.uk

${ }^{1}$ Centre for Research in Biosciences, Faculty of Health and Applied Sciences,

University of the West of England, Coldharbour Lane, Frenchay, Bristol BS16

1QY, UK

Full list of author information is available at the end of the article
} 


\section{Background}

Hypoxia is defined as the state in which the availability or delivery of oxygen is insufficient to meet tissue demand [1]. It is a common feature of aggressive cancers, as angiogenesis cannot match the rate of tumour growth [2]. Insufficient angiogenesis results in poor delivery of nutrients, and this coupled with severe hypoxic stress can trigger apoptosis [3]. Remarkably, cancer cells are often able to survive the harsh conditions associated with hypoxia.

Hypoxic tumours are more difficult to treat. In radiotherapy, high-energy photons directed at the tumour site react with biological molecules to form DNA-damaging molecules, causing cancer cells to undergo apoptosis leading to shrinkage of the tumour [4]. Therefore, in hypoxic regions where there is a low level of oxygen molecules, radiotherapy is often not an effective form of treatment. In addition, tumour hypoxia can lead to resistance to chemotherapeutic drugs. A review published by Brown outlines three reasons for this [5]. Firstly, with diminished vasculature, drugs are unable to travel to hypoxic regions. Secondly, many chemotherapeutics target rapidly proliferating cells; however hypoxic cells tend to progress through the cell cycle much more slowly. Thirdly, hypoxia increases the expression of proteins involved in drug resistance, such as metallothioneinIIA (MT-IIA) involved in cisplatin resistance [6] and periostin involved in arsenic trioxide resistance [7]. A greater understanding of how tumour cells are able to adapt to hypoxia could help improve existing therapies or even suggest new treatment solutions.

Changes in alternative splicing of pre-mRNA may be one mechanism through which cells are able to adapt to hypoxic conditions. Pre-mRNA splicing involves the excision of introns and precise joining of exons to form the mature RNA [8]. 95\% of pre-mRNAs are alternatively spliced in humans [9], giving rise to at least 100,000 distinct proteins [10] despite there only being an estimated 20,000 protein-coding genes. Splice isoforms encode proteins with distinct cellular functions. Hypoxia has been shown to have a significant effect on the alternative splicing of genes in normal endothelial cells $[11,12]$; in cartilage endplate-derived stem cells [13]; in Hep3B liver [14] and in MCF7 breast cancer cell lines [15]. Hypoxia reduces expression of MAX (MYCassociated factor $\mathrm{X}$ ) in endothelial cells through increased unproductive splicing [16]. The splicing of the SMN2 gene is also modified by hypoxia in the context of Spinal Muscular Atrophy [17]. While several studies utilised exon arrays to study changes in exonic splicing during hypoxia, a recent study conducted in MCF7 breast cancer cells utilised whole transcriptome RNAseq identifying intron retention as the most commonly altered alternative splicing event [15].
Given these notable changes in alternative splicing in hypoxia, the question is which regulators of splicing are involved? The aim of the present study is firstly to examine the effect of hypoxia on alternative splicing in a prostate cancer cell line model, and secondly to examine the expression of several splice factors and splice factor in response to hypoxia.

\section{Methods}

Cell lines, hypoxia treatments and CLK1 inhibition

The prostate cancer cell lines, PC3 (Sigma-Aldrich, 90112714), VCaP (Sigma-Aldrich, 06020201) and DU145 (ATCC, HTB-81), the normal prostate epithelial PNT2 cell line (ECACC, 95012613), the colorectal cancer cell line HT29 (Sigma-Aldrich, 91072201), and the breast cancer cell line MCF7 (Sigma-Aldrich, 86012803) were cultured in high glucose Dulbecco's modified Eagle's medium (DMEM), supplemented with 10\% fetal bovine serum (FBS) and 1\% L-glutamine-penicillin-streptomycin and grown at $37{ }^{\circ} \mathrm{C}$ with $5 \% \mathrm{CO}_{2}$. Hypoxia was attained in a modular incubator chamber (MIC-101; Billups-Rothenberg, USA) using a gas mixture containing; $1 \% \mathrm{O}_{2} / 5 \% \mathrm{CO}_{2} / 94 \% \mathrm{~N}_{2}$ (BOC, UK). The chamber was flooded with the hypoxic gas mixture for $2 \mathrm{~min}$ and then sealed and stored in an incubator for $48 \mathrm{~h}$ at $37^{\circ} \mathrm{C}$ in $5 \% \mathrm{CO}_{2}$. The normoxic control was stored in the same incubator for the same amount of time. CLK1 was inhibited with the benzothiazole TG003 (Sigma-Aldrich) at $10-50 \mu \mathrm{M}$; the TG003 stock was dissolved in dimethylsulphoxide (DMSO).

\section{RNA extraction}

RNA was extracted using Tri reagent (Sigma-Aldrich) as per manufacturer's instructions with the following modifications; the first three centrifugations (homogenate, phase separation and RNA isolation) were conducted at $10,000 \mathrm{~g}$, phase separation centrifugation was for $30 \mathrm{~min}$; and $0.1 \mathrm{ml}$ chloroform was used for phase separation. RNA pellets were washed with $0.5 \mathrm{ml} 70 \%$ ethanol and centrifuged at $3500 \mathrm{~g}$, and the wash step was repeated twice. RNA pellets were resuspended in $30 \mu \mathrm{l}$ nucleasefree $\mathrm{H}_{2} \mathrm{O}$ (Promega). Genomic DNA was removed using the Precision DNase kit (Primerdesign, UK). Total RNA concentration was determined using a Nanodrop spectrophotometer (ThermoFisher Scientific, Delaware).

\section{CDNA synthesis and standard PCR}

cDNA was synthesised with the GoScript reverse transcription system (Promega, UK). Total RNA was reverse transcribed using a 1:1 mixture of random primers and oligo(dT). The GoTaq hot start polymerase kit (Promega, UK) was used to perform standard PCR. PCR conditions were: initial denaturation at $94{ }^{\circ} \mathrm{C}$ for $2 \mathrm{~min}$; then $35-40$ cycles: $94{ }^{\circ} \mathrm{C}$ for $30 \mathrm{~s} ; 58{ }^{\circ} \mathrm{C}$ for $30 \mathrm{~s}$; and 
$72{ }^{\circ} \mathrm{C}$ for $30 \mathrm{~s}$ followed by a final extension at $72{ }^{\circ} \mathrm{C}$ for 5 min. Primer sequences used in standard PCR are shown in Additional file 1: Table S1. PCR products were run on $2 \%(w / v)$ agarose gels for $1 \mathrm{~h}$ at $95 \mathrm{~V}$ and analysed using FluorChem Q software, Alpha Innotech MultiImage III. Optical density peak values were generated with ImageJ software. Excel was used to calculate the percentage splicing index (PSI $/ \psi)$ where $\psi=$ exon inclusion/ exon inclusion + exon skipping band intensities.

\section{High-throughput PCR}

High-throughput PCR was performed at the RNOmics platform at the University of Sherbrooke, Canada. RNA integrity was determined using an Agilent 2100 Bioanalyzer (Agilent Technologies). $2.2 \mu \mathrm{g}$ total RNA were reverse transcribed with Transcriptor reverse transcriptase, random hexamers, dNTPs (Roche Diagnostics), and 10 units of RNAse OUT (Invitrogen) in $20 \mu \mathrm{l}$. All primers were resuspended in $20-100 \mu \mathrm{M}$ stock solutions in Tris-EDTA buffer (IDT) and diluted as primer pairs to $1.2 \mu \mathrm{M}$ in RNase and DNase-free water (IDT). RTPCR reactions were performed using $10 \mathrm{ng}$ cDNA as template in a $10 \mu \mathrm{L}$ final volume containing $0.2 \mathrm{mmol} / \mathrm{L}$ $\mathrm{dNTP}, 1.5 \mathrm{mmol} / \mathrm{L} \mathrm{MgCl}_{2}, 0.6 \mu \mathrm{mol} / \mathrm{L}$ each primer, and 0.2 units of Platinum Taq DNA polymerase (Invitrogen). After an initial denaturation at $95{ }^{\circ} \mathrm{C}$ for $2 \mathrm{~min}, 35$ PCR cycles were performed; $94{ }^{\circ} \mathrm{C} 30 \mathrm{~s}, 55{ }^{\circ} \mathrm{C} 30 \mathrm{~s}$, and $72{ }^{\circ} \mathrm{C}$ $60 \mathrm{~s}$, followed by a final extension step at $72{ }^{\circ} \mathrm{C}$ for
2 min. PCR reactions were carried out on the GeneAmp PCR System 9700 (ABI), and the amplicons were examined by automated microcapillary electrophoresis using Caliper LC-90 instruments (Caliper LifeSciences). The percent spliced index (PSI, $\psi$ ) was calculated as the ratio of the band intensity of the exon inclusion amplicon divided by the sum of both inclusion and exclusion amplicon band intensities, measured using ImageJ software. The selection of cassette exons was based on genes from the NCBI RefSeq database associated with cancer and apoptosis pathways, all of which suitable for PSI analysis $[18,19]$.

\section{qRT-PCR}

qRT-PCR was performed in 96-well plates as per the protocol by Primerdesign (UK), using SensiFAST Sybr Hi-Rox kit (Bioline, UK) mastermix. Three technical repeats were conducted per experimental sample, and nuclease free water was used as a negative control. qRT-PCR plates were run on an ABI 7300 qRT-PCR thermal cycler (Applied Biosciences). PCR conditions were as follows; initially $95{ }^{\circ} \mathrm{C}$ for $10 \mathrm{~min}$; then $95{ }^{\circ} \mathrm{C}$ for $15 \mathrm{~s} ; 60{ }^{\circ} \mathrm{C}$ for $1 \mathrm{~min}$ for 40 cycles. Melting curve conditions were $95{ }^{\circ} \mathrm{C}$ for $15 \mathrm{~s} ; 60{ }^{\circ} \mathrm{C}$ for $1 \mathrm{~min} ; 95^{\circ} \mathrm{C}$ for $15 \mathrm{~s}$. Primer sequences used in qRT-PCR are shown in Additional file 2: Table S2. CT values were normalised to the $U B C$ and RPL13A housekeeping genes. All results were calculated using Excel software (Microsoft, USA).

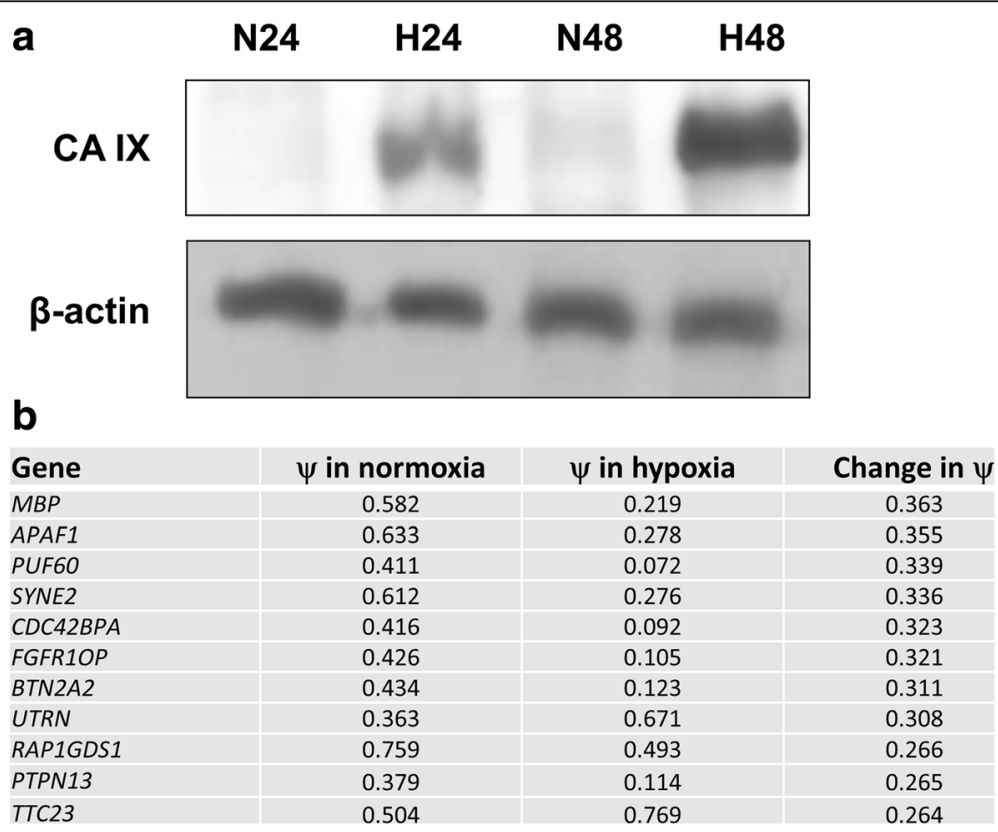

Fig. 1 Exposure of PC3 cells to hypoxia (1\% oxygen) results in changes in alternative splicing of cancer associated genes. PC3 prostate cancer cells were exposed to $1 \%$ oxygen or normoxic conditions for up to $48 \mathrm{~h}$. a Protein samples were extracted at 24 and $48 \mathrm{~h}$ time points and western blotted for CA IX (carbonic anhydrase 9), a hypoxia marker; $\mathrm{N}$ refers to normoxia and $\mathrm{H}$ to hypoxia. $\beta$-actin was used as a loading control. b RNA samples were extracted at $48 \mathrm{~h}$ and sent to the RNomics platform at the University of Sherbrooke, Canada, for high-throughput PCR analysis of the rate of inclusion of 600 cancer-associated cassette exons. Genes whose $\psi$ indexes (proportion of exon included) changed by $>25 \%$ are listed 


\section{Protein extraction and quantification}

For the extraction of protein, cells were washed with phosphate buffered saline (PBS) before the addition RIPA lysis buffer (Sigma, UK) and phosphatase inhibitor tablets (Complete Mini EDTA-free PI tablets, Roche Diagnostics, UK). Cell lysates were collected in $1.5 \mathrm{ml}$ Eppendorf tubes and kept on ice. The Pierce BCA assay (Thermo Fisher Scientific, USA) was used to measure protein concentration.

\section{Western blotting}

Protein samples were mixed 1:1 with $2 \times$ Laemmli buffer (Sigma, UK) and incubated at $100{ }^{\circ} \mathrm{C}$ for $5 \mathrm{~min}$ before being chilled on ice. Protein samples of equal amounts were subjected to SDS-PAGE and transferred to PDVF membranes. Membranes were incubated at $4{ }^{\circ} \mathrm{C}$ overnight with one of the following antibodies; anti-CA IX (M75 monoclonal antibody, Novus Biologicals); anti-SRSF1 (sc-33652, SantaCruz Biotechnology, UK); anti-CLK1 (R1471-1 s, Abiocode, USA); anti-phospho SR(1H4) (sc-13509, SantaCruz Biotechnology, UK); anti- $\beta$-actin (ab8226, Abcam, UK). Horse anti-mouse IgG HRP-linked antibody (7076S, Cell Signalling, UK) was used to detect all antibodies apart from anti-CLK1, which was detected by goat anti-rabbit
IgG HRP-linked antibody (7074, Cell Signalling, UK). Laminata Forta Western HRP substrate (Millipore, UK) was used to image protein bands.

\section{Analysis of promoter sequences}

The promoter sequences of SRSF1, SRSF2, SRSF3, SAM68, HuR, hnRNP A1, CLK1 and SRPK1 splice factors and splice factor kinases were examined for the presence of HIF response element (HRE) sequences (5'RCGTG-3') using the Eukaryotic Promoter Database (http://epd.vital-it.ch/). Parameters were set from - 1000 to +100 of the transcription start site (TSS), as HIF- $1 \alpha$ mostly binds close to the TSS [20].

\section{Statistical analysis}

All data obtained for the standard and qRT-PCR experiments was subjected to Shapiro-Wilks and Bartlett's test in order to deduce the distribution and variance of the data, respectively. For the standard PCR, data that was found to be normally distributed and homoschedastic was then subjected to a student's T-test in order to examine the statistical significance of the data. Results found not to be normally distributed and/or heteroschedastic were subjected to a Mann Whitney U statistical

Table 1 List of genes whose $\psi$ value change by over 25\% in hypoxia

\begin{tabular}{|c|c|c|c|}
\hline Gene name & Gene function & Function of splice isoform & $\begin{array}{l}\text { Change in splice } \\
\text { isoform expression after hypoxia }\end{array}$ \\
\hline APAFI & $\begin{array}{l}\text { Required for the formation of the apoptosome } \\
\text { in apoptosis [32] }\end{array}$ & $\begin{array}{l}\text { Exon } 17 \text { a codes for a WDR domain required } \\
\text { for the formation of the apoptosome [33] }\end{array}$ & $\begin{array}{l}\text { Exon 17a skipping is favoured } \\
\text { in hypoxia }\end{array}$ \\
\hline BTN2A2 & Involved in immune tolerance in cancer & $\begin{array}{l}\text { Exon } 5 \text { skipping forms a truncated protein that } \\
\text { negatively regulates the full length protein } \\
\text { involved in immune tolerance [39] }\end{array}$ & $\begin{array}{l}\text { Increased exon inclusion, which } \\
\text { promotes immune tolerance }\end{array}$ \\
\hline$C D C 42 B P A$ & $\begin{array}{l}\text { Reorganisation of the cytoskeleton, formation } \\
\text { of filopodia and assignment of cellular polarity. } \\
\text { Implicated in cancer cell motility and invasion }\end{array}$ & Unknown function & $\begin{array}{l}\text { Decrease in exon inclusion in } \\
\text { hypoxia. }\end{array}$ \\
\hline FGFR1OP & $\begin{array}{l}\text { Ciliogenesis, cellular motility, cell growth and } \\
\text { cell cycle progression }\end{array}$ & Unknown function & $\begin{array}{l}\text { Exon skipping favoured in } \\
\text { hypoxia }\end{array}$ \\
\hline MBP & $\begin{array}{l}\text { Formation of the myelin sheath. Elevated in } \\
\text { breast cancer and lung cancer patients with } \\
\text { brain metastasis }\end{array}$ & Unknown function. & $\begin{array}{l}\text { Exon skipping favoured in } \\
\text { hypoxia. }\end{array}$ \\
\hline PTPN13 & $\begin{array}{l}\text { Competing roles as a tumour suppressor } \\
\text { and oncogene }\end{array}$ & Unknown function. & $\begin{array}{l}\text { Decrease in exon inclusion in } \\
\text { hypoxia }\end{array}$ \\
\hline PUF60 & $\begin{array}{l}\text { Modulates alternative splicing through } \\
\text { recognition of } 3^{\prime} \text { splice sites. Regulates } \\
\text { c-myc transcription }\end{array}$ & $\begin{array}{l}\text { Exon } 5 \text { skipping results in expression of an isoform } \\
\text { known as FIR, a c-myc repressor }[40,41]\end{array}$ & $\begin{array}{l}\text { Expression of anti-oncogenic } \\
\text { FIR isoform favoured in hypoxia. }\end{array}$ \\
\hline RAPIGDS1 & $\begin{array}{l}\text { Activates multiple small GTPases in the Rho } \\
\text { and Ras families }\end{array}$ & $\begin{array}{l}\text { Exon } 5 \text { skipping produces SmgGDS- } 558 \text { which } \\
\text { plays a greater role in proliferation and NFkB } \\
\text { activity than the full-length SmgGDS- } 607 \text { splice } \\
\text { variant [42]). }\end{array}$ & $\begin{array}{l}\text { Hypoxia favours the smgGDS- } \\
558 \text { isoform. }\end{array}$ \\
\hline SYNE2 & $\begin{array}{l}\text { Influences the shape and migration properties } \\
\text { of cells }\end{array}$ & $\begin{array}{l}\text { Exon } 107 \text { encodes a domain required for scaffolding } \\
\text { for protein-protein interactions [43]. }\end{array}$ & $\begin{array}{l}\text { Exon skipping favoured in } \\
\text { hypoxia }\end{array}$ \\
\hline TTC23 & $\begin{array}{l}\text { Unknown function but expression linked to } \\
\text { cervical, bladder and prostate cancers. }\end{array}$ & Unknown function & $\begin{array}{l}\text { Exon inclusion favoured in } \\
\text { hypoxia. }\end{array}$ \\
\hline UTRN & Maintenance of the cytoskeleton & Unknown function & $\begin{array}{l}\text { Exon skipping increased in } \\
\text { hypoxia. }\end{array}$ \\
\hline
\end{tabular}




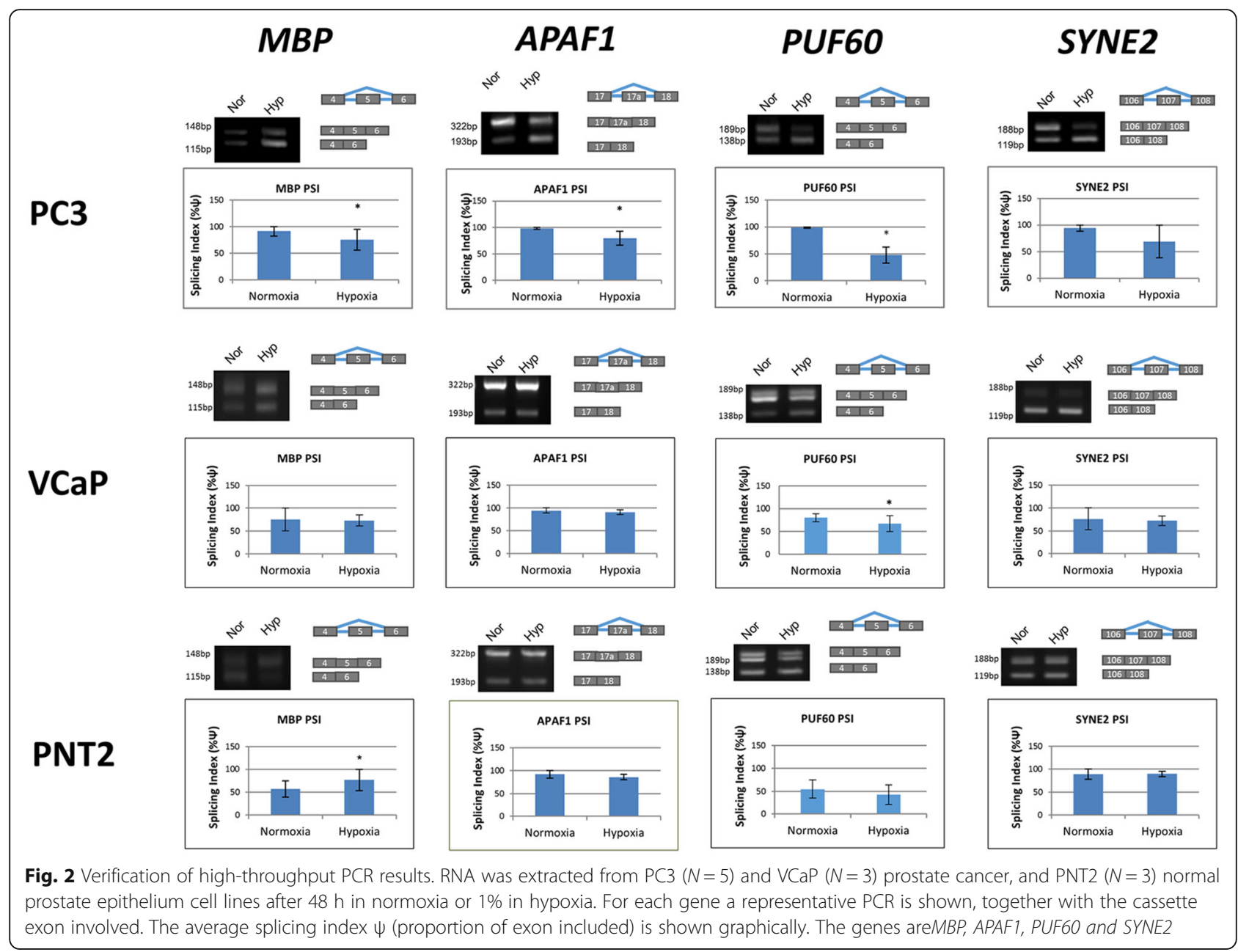

test of significance. A Mann Whitney U non-parametric test was used for test for statistical significance for all the real-time PCR data. For all results obtained from the standard PCR and real-time PCR experiments, the means were calculated from the results and plotted on graphs, and error bars were added using the $95 \%$ confidence interval.

\section{Results}

\section{High-throughput PCR analysis of alternative splicing in} hypoxic PC3 cells

It is clear that cells can adapt to hypoxic conditions by altering alternative splicing programmes [11-17]; however the effect of hypoxia on alternative splicing in prostate cancer cells has not been examined. We utilised a hypoxic chamber, perfused with an air mixture containing 1\% oxygen, and exposed PC3 cells (androgen independent, established from a grade 4 prostatic adenocarcinoma) to these conditions for up to $48 \mathrm{~h}$. To confirm the establishment of a hypoxic environment we measured the hypoxia marker carbonic anhydrase IX
(CA IX). CA IX is highly induced in hypoxia as it facilitates the adaptation of cells to a severely altered $\mathrm{pH}$ environment [21]. Consistent with hypoxic conditions a significant induction of CA IX was observed (Fig. 1a). RNA was extracted from PC3 cells $48 \mathrm{~h}$ after seeding, one set of cells growing in normoxia and another in $1 \%$ oxygen for $48 \mathrm{~h}$. The RNA was sent for analysis at the RNOmics platform at the University of Sherbrooke, Canada. The RNOmics platform utilises a highthroughput reverse transcription-PCR platform to analyse cassette exon events associated with 600 cancerassociated genes; the approach is called LISA (Layered and Integrated system for Splicing Annotation) $[18,19]$. Cassette exon inclusion is measured as the value PSI $(\psi)$ where $1=$ complete inclusion, and 0 complete exon skipping. Out of the LISA data set we found that 11 genes showed a change in $\psi$ value greater than $25 \%$ compared to normoxic values (Fig. 1b; MBP, APAF1, PUF60, SYNE2, CDC42BPA, FGFR1OP, BTN2A2, UTRN, RAP1GDS1, PTPN13, and TTC23). We note that several of the genes are involved in the regulation of cytoskeletal 


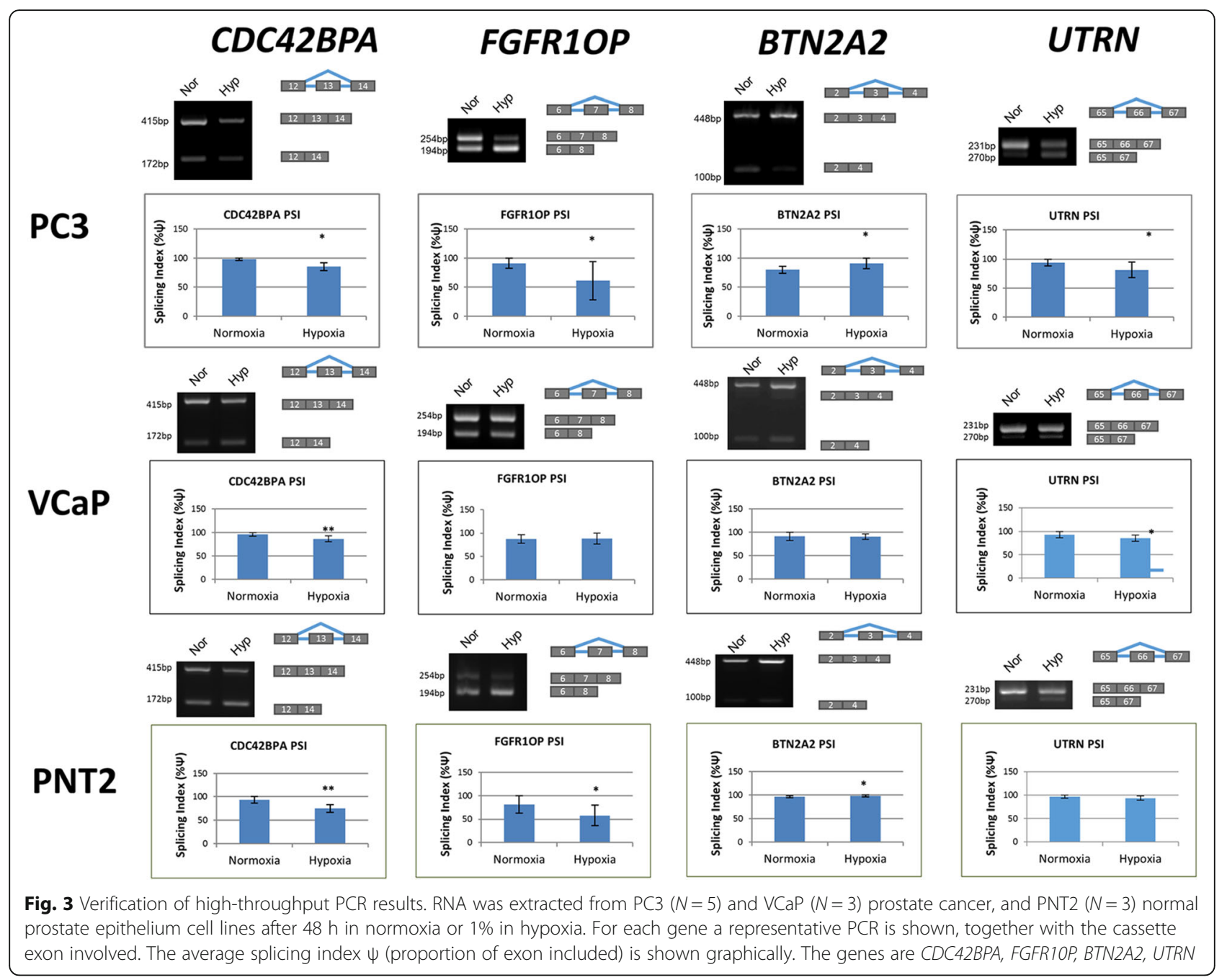

architecture. The properties of the alternative splice isoforms are summarised in Table 1.

\section{Verification of high-throughput PCR results}

In order to validate the LISA results the experiment was repeated in three cell lines. In each case an equivalent number of $\mathrm{PC} 3$ and DU145 prostate cancer cells and the normal epithelial cell line PNT2 were exposed to $1 \%$ oxygen for $48 \mathrm{~h}$. CA IX levels were elevated in each repeat experiment (data not shown). RNA was extracted and cDNA synthesized, and PCR performed using the same primers used in the RNOmics platform high-throughput PCR assay (Additional file 1: Table S1). To the set of 11 genes from the LISA analysis, we added CASP9 (caspase-9), an important apoptosis marker (not present in the Sherbrooke LISA gene set). CASP9 expresses several splice isoforms. Caspase 9b arises from skipping of exons 3-6, resulting in a truncated, anti-apoptotic isoform, whereas caspase 9a includes exons 3-6 encoding the functional pro-apoptotic isoform. Changes in $\psi$ were statistically consistent in PC3 cells, confirming the findings of the high-throughput PCR. Quantification of PCR bands using Image J was performed for each of the repeats and a representative PCR gel is shown in each case (Figs. 2, 3, and 4).

\section{Expression of splice factor kinases in hypoxic PC3 cells} Changes in alternative splicing in hypoxia are likely to arise from changes in the expression and activity of splice factors and of splice factor kinases that modulate their function. We began by selecting a set of splice factors that have been shown to be associated with abnormal splicing patterns in cancer. These include three SR (serine- arginine rich) proteins SRSF1 (a proto-oncogene [22]), SRSF2 and SRSF3; the splice factor SAM68 (involved in signal transduction), HuR and hnRNPA1; and the splice factor kinases CLK1 and SRPK1. Several publications have identified a core hypoxia inducible factor (HIF) response 


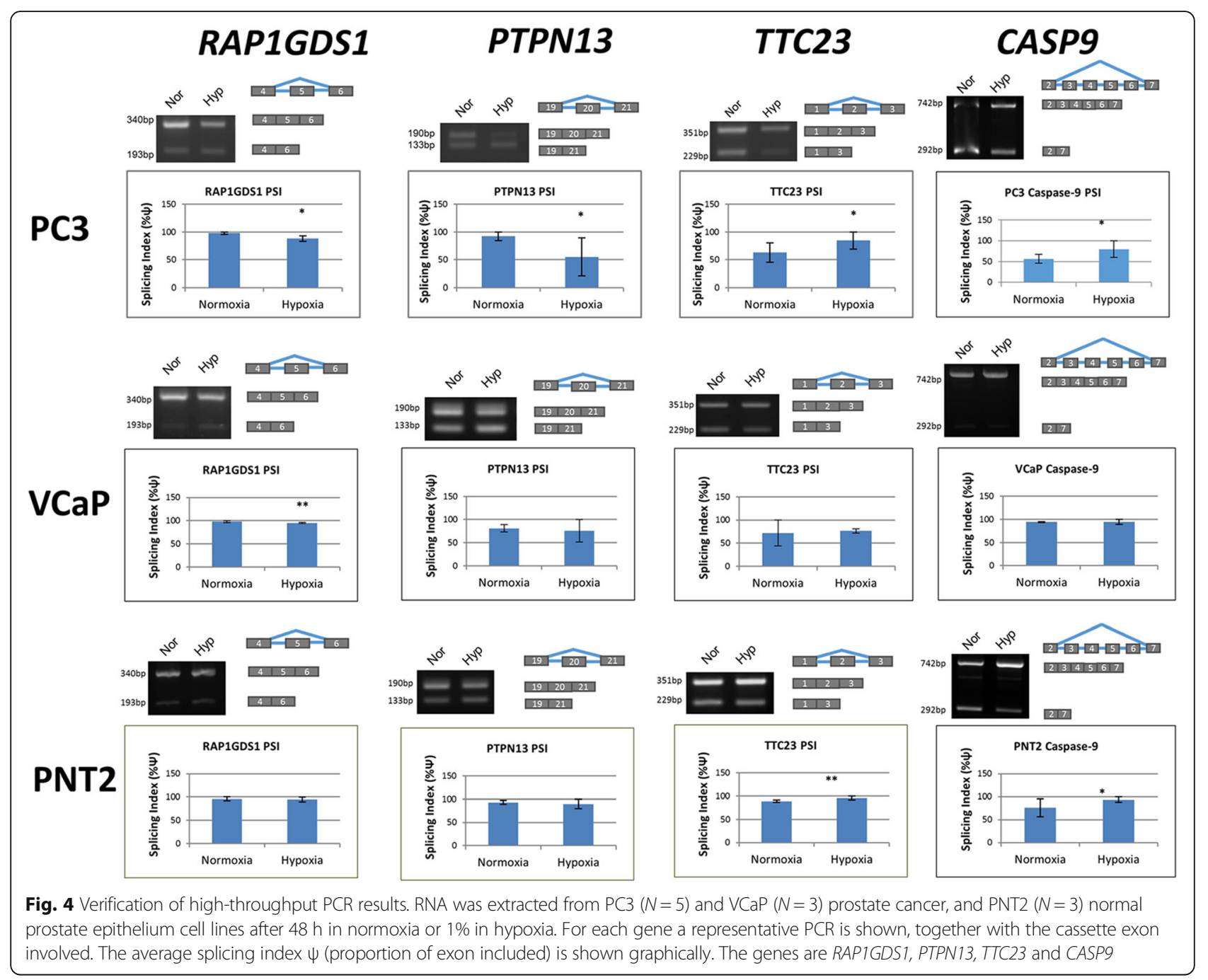

element that is conserved from animals to zebrafish (5'-RCGTG-3'). Therefore, we examined their promoter sequences using the eukaryotic promoter database with parameters set from -1000 to +100 of the transcription start site, and noticed the presence of 1-5 HIF binding sites (Fig. 5a). HIF binding sites were present in all gene promoters except for the splice factor kinase SRPK1 (Fig. 5a). Next we examined their expression in hypoxia using qRT-PCR. The expression of all splice factor and splice factor kinases appeared to increase in hypoxia (Fig. 5b). Given that CLK1 has previously been shown to be HIF-inducible [23] we confirmed its increased expression, along with its substrate the splice factor SRSF1 by western blot (Fig. 5c). We also used a monoclonal antibody, mAb104, that specifically recognises phosphorylated SR proteins [24] and noticed elevated phosphorylation of SR proteins in hypoxia, consistent with an increased activity of splice factor kinases (Fig. 5d).
Induction of CLK family expression in hypoxia We examined the expression of the CLK (CDC-like) splice factor kinase CLK1 in more detail. The CLK family comprises four genes in humans, termed CLK1-4. Among these, CLK1 and CLK4 are very similar in amino-acid sequence. CLK1, CLK2 and CLK4 are ubiquitously expressed, whereas CLK3 is most expressed in testis [25]. Among the CLKs, CLK1 is the most highly studied, and its interaction with its substrate SRSF1 is well understood [26]. Firstly we looked at the induction of CLK1, and for comparison CLK3 in PC3 cells in three different hypoxic conditions, $1.0 \%, 0.2 \%$ and $0.0 \%$ oxygen. We observed an induction of CLK1 in all three hypoxic conditions after $16 \mathrm{~h}$ (Fig. 6a); unexpectedly, we also observed that CLK3 was induced. For comparison, Affymetrix microarray experiments were performed on DU145 prostate, HT29 colorectal and MCF7 breast cancer cell lines exposed to $0.0 \%$ hypoxia [27]. We wanted to determine 


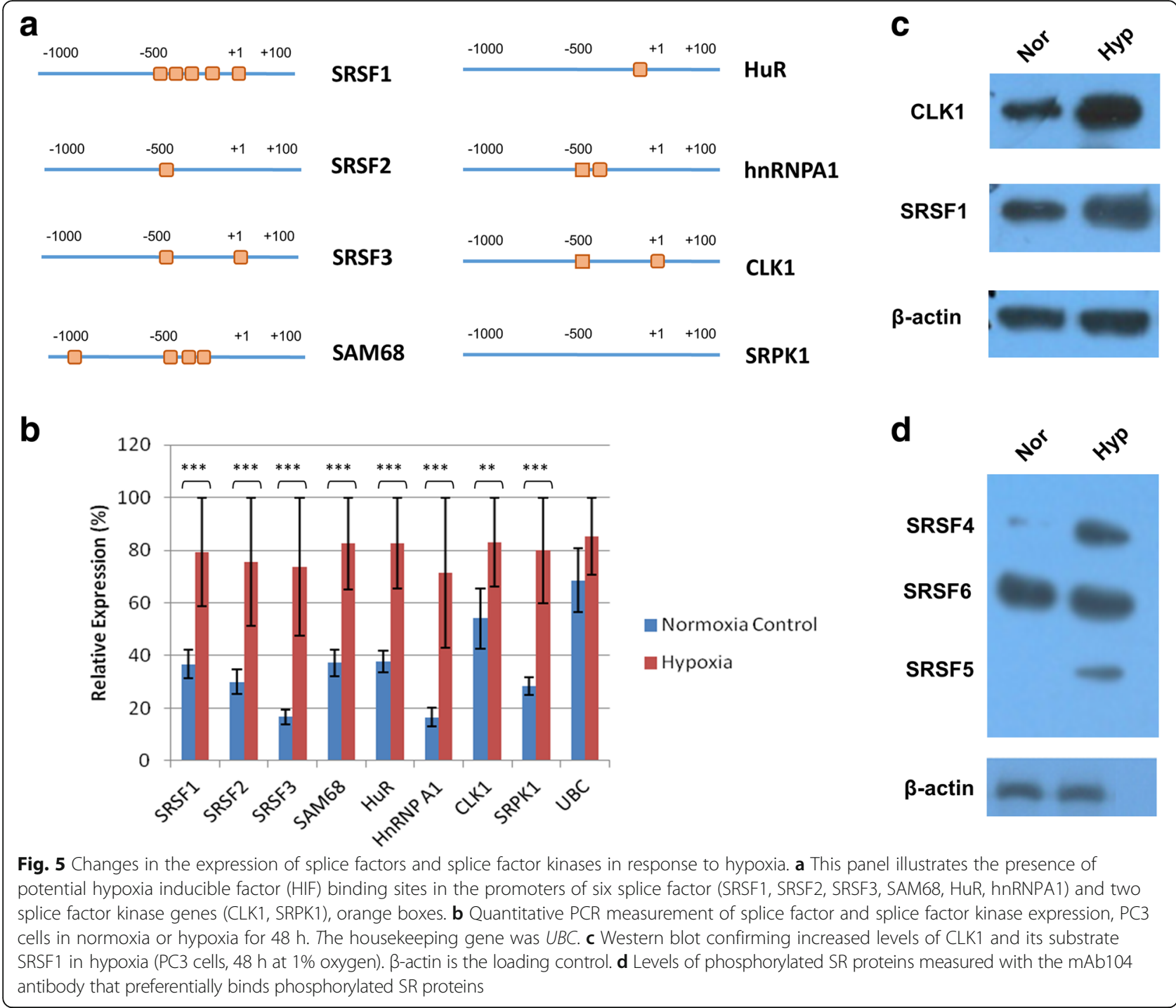

whether or not CLK induction during hypoxia is specific to PC3 prostate cancer cells. We observed strong induction of CLK1 and CLK3 in all three cell lines, but not CLK2 and CLK4 (Fig. 6b). Finally, we inhibited CLK1 activity in PC3 cells using the benzothiazole inhibitor TG003 [28] in order to determine the effect on CASP9 alternative splicing. We found that the expression of caspase $9 \mathrm{~b}$, clearly reduced in hypoxia (Fig. 4c), increased following CLK1 inhibition (Fig. 6c).

\section{Discussion}

Recently there has been interest in examining hypoxiadriven changes in alternative splicing. A genome-wide study was conducted in hypoxic endothelial cells using the Affymetrix human exon 1.0 array [12]. Alterations were found in 294 genes including nine alternative splicing events that were not previously related to hypoxia. The changes involved to a large extent genes involved in angiogenesis, glucose metabolism, cell cycle, DNA repair, and cytoskeletal remodelling. In the DNA damage response, hypoxia drives the alternative splicing of genes towards noncoding isoforms through increased intron retention [29]. In a similar vein, in endothelial cells hypoxia promotes the expression of a splice isoform of MAX (Myc associated factor X) that is degraded by nonsense-mediated decay, and another splice isoform that encodes an unstable protein; the net effect is less active MAX protein is produced [16]. Investigations using the Hep3B hepatocarcinoma cell line revealed the hypoxia altered alternative splicing patterns of HIF and non-HIF genes including $C A I X, R A P 1 G D S 1$ and $M B P$ [14]; $M B P$ was also identified in our high throughput PCR screen (Fig. 1b). In MCF7 breast cancer cells hypoxia was found to affect the alternative splicing of genes that are involved in a number of cancer-driving processes including angiogenesis, cell growth and 


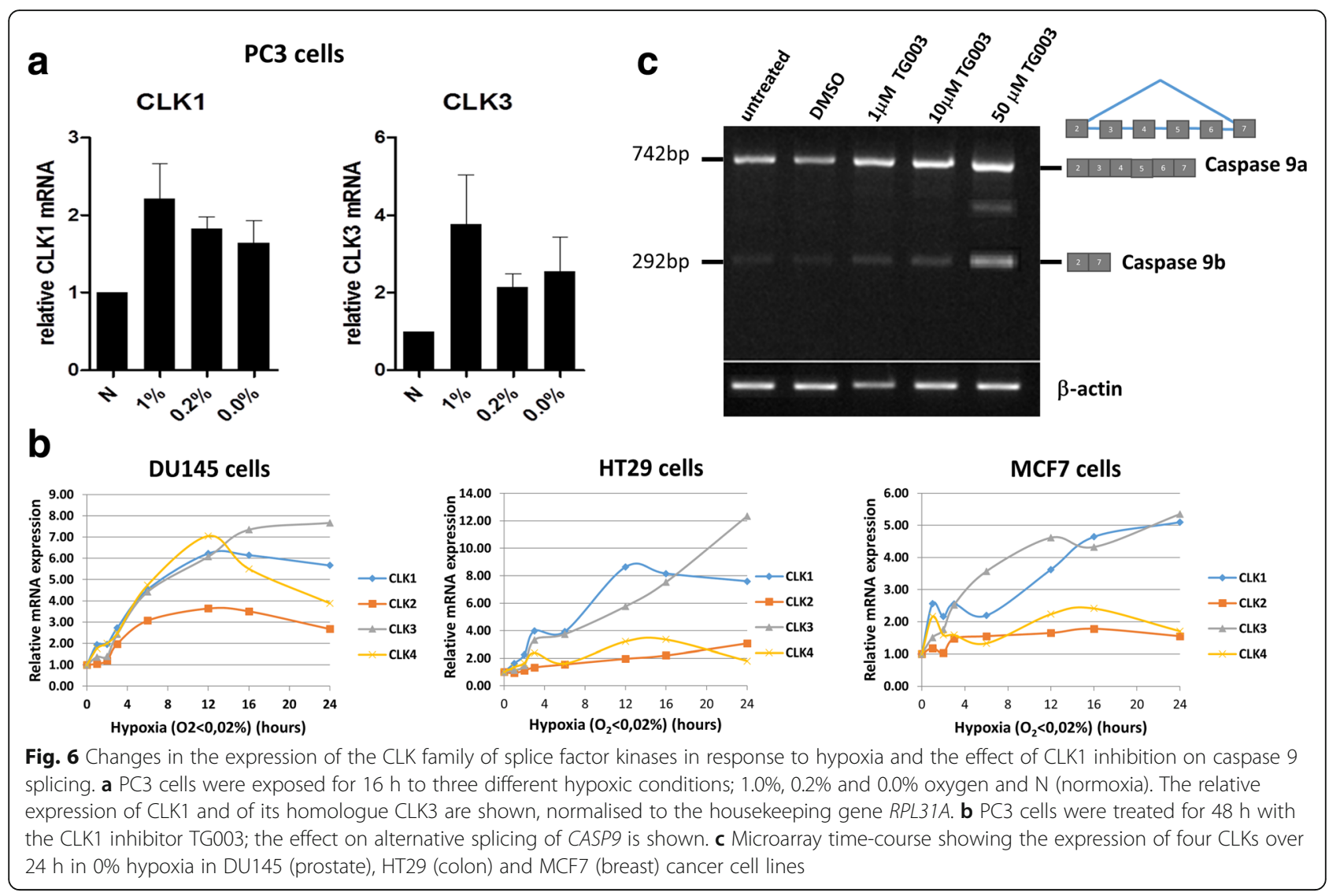

apoptosis, suggesting that hypoxia plays a role in cancer progression [15]. Furthermore, the latter study also confirmed intron retention as the most common type of splicing event to be altered in hypoxia. Typically, intron retention can result in the use of a premature stop codon, which in turn can trigger nonsense mediated decay (NMD) or produce a truncated protein. Thus there are a number of clearly documented cases of cells adapting to hypoxia by changing alternative splicing of key genes [11-17]. In the present study we can confirm that changes in alternative splicing of cancer genes also occur in response to hypoxia in the widely used prostate cancer cell lines $\mathrm{PC} 3$ and $\mathrm{VCaP}$, and in the normal epithelial cell line PNT2.

Hypoxic tumour cells can become resistant to apoptosis by expressing apoptosis inhibitors such as IAP-2 [30]. There are several components of the apoptosis machinery and genes express pro- or anti-apoptotic splice isoforms (BCL2L1, MCL1, CASP9 and APAF1 are notable examples). A recent study shows that the pharmacological inhibition of APAF1 allows cells in which apoptosis is induced by hypoxia to recover [31-33]. We examined the alternative splicing of CASP9, and noted that in hypoxia expression of the pro-apoptotic full length caspase 9a isoform increased significantly in PC3 and PNT2 cells (Fig. 4c). We suggest that changes in alternative splicing in hypoxia result in a different balance of splice isoforms that contribute to the induction of apoptosis.

We examined the promoters of a representative set of splice factors and splice factor kinases, and found putative HIF consensus binding sites in 7/8 (the exception being SRPK1). The expression of all eight splice factors and kinases appeared to increase in hypoxia, suggesting a general activation of the machinery of alternative splicing in conditions of severe hypoxic stress. We turned our attention to the CDC-2 like (CLK) family of splice factor kinases, because recent literature has identified an increase in expression of CLK1 in response to hypoxia [23, 34]. We confirmed the induction of CLK1, not just in PC3 cells, but also in another prostate cancer cell line, DU145, and in HT29 colorectal and MCF7 breast cancer cell lines (Fig. $6 \mathrm{a}$ and $\mathrm{b})$. We observed the parallel induction of CLK1 and CLK3 in the four cell lines. CLK3 is best known for its expression in normal testis [25]; however we suggest that along with CLK1, CLK3 might contribute to adaptation to hypoxia in cancer cells.

To address the functional significance of CLK1 induction in the context of alternative splicing in hypoxia, we treated PC3 cells with the CLK1 inhibitor, the benzothiazole TG003 [28]. Inhibition of CLK1 with up to $50 \mu \mathrm{M}$ TG003 increased the expression of caspase $9 \mathrm{~b}$, the antiapoptotic isoform in which exons 3-6 are skipped (Fig. 
6c). There is interest in the potential of targeting CLK1 in the context of the influenza [35] and HIV-1 viruses [36] and in cancer cells [37, 38]. The fact that CLK kinases appear to help cancer cells adapt to hypoxia suggests that they could be useful therapeutic targets.

\section{Conclusions}

This study demonstrates that there are significant changes in exon inclusion rates in a range of cancerassociated genes in $\mathrm{PC} 3$ prostate cancer cells exposed to $1 \%$ oxygen hypoxic conditions. The expression of splice factors and splice factor kinases also increases significantly in hypoxia; in particular we observed a consistent induction of CLK1 and CLK3 in four independent cell lines. We suggest that targeting CLK kinases may provide benefit in the treatment of cancers in which tumour hypoxia contributes to resistance to therapy.

\section{Additional file}

Additional file 1: Table S1. Forward (F) and reverse $(R)$ primer sequences for all human genes amplified using standard PCR. The target sites of the primers, including the exonic locations, are indicated. (DOCX $13 \mathrm{~kb}$ )

Additional file 2: Table S2. Forward and reverse primer sequences for all human genes amplified using qRT-PCR. Details of the primers using in qRT-PCR analysis. (DOCX $13 \mathrm{~kb}$ )

\section{Abbreviations}

CLK: cdc-like kinase; HIF: Hypoxia inducible factor; SR: Serine-arginine rich

\section{Acknowledgments}

We are very grateful to Professor Silvia Pastorekova for hosting EB in her laboratory and providing valuable expertise in setting up hypoxia experiments. We are very grateful to Professor Masatoshi Hagiwara for advice on CLK1 inhibition. We would also like to thank David Corry for valuable technical assistance. $\mathrm{ML}$ is a member of the European Organisation for Research and Treatment of Cancer (EORTC) Pathobiology group.

\section{Funding}

This study was supported by a PhD bursary to EB awarded by the University of the West of England, Bristol, through Quality Research (QR) funds.

\section{Availability of data and materials}

The authors are happy to share all data and pertinent materials.

\section{Authors' contributions}

All authors have read and approved the manuscript. EB performed the hypoxia experiments, PCR verifications, and the analysis of splice factor expression with input from SP and SU. PT, MD and EL produced the highthroughput PCR data. RK performed the in-depth analysis of CLK expression. IW and $\mathrm{JH}$ contributed to the supervision of EB. ML was the principal investigator.

\section{Ethics approval}

Not applicable.

\section{Consent for publication}

Not applicable.

\section{Competing interests}

The authors declare that they have no competing interests.

\section{Publisher's Note}

Springer Nature remains neutral with regard to jurisdictional claims in published maps and institutional affiliations.

\section{Author details}

${ }^{1}$ Centre for Research in Biosciences, Faculty of Health and Applied Sciences, University of the West of England, Coldharbour Lane, Frenchay, Bristol BS16 1QY, UK. ${ }^{2}$ Z8 Pavillon de Recherche Appliquée sur le Cancer (PRAC),

Université de Sherbrooke, 3201 Jean-Mignault, Sherbrooke, Québec J1E 4K8,

Canada. ${ }^{3}$ Department of Radiation Oncology (Maastro Lab), GROW-School for Oncology and Developmental Biology, Maastricht University, Maastricht, The Netherlands.

Received: 21 July 2017 Accepted: 15 March 2018

Published online: 02 April 2018

\section{References}

1. Loboda A, Jozkowicz A, Dulak J. HIF-1 versus HIF-2 - is one more important than the other? Vasc Pharmacol. 2012;56:245-51.

2. Evans SM, Koch CJ. Prognostic significance of tumor oxygenation in humans. Cancer Lett. 2003;195:1-16.

3. Semenza G. HIF-1: mediator of physiological and pathophysiological responses to hypoxia. J Appl Physiol. 2000;88:1474-80.

4. Grimes DR, Partridge M. A mechanistic investigation of the oxygen fixation hypothesis and oxygen enhancement ratio. Biomed Phys Eng Express. 2015; 1:045209.

5. Brown JM. The hypoxic cell: a target for selective cancer therapy —eighteenth Bruce F. Cain memorial award lecture. Cancer Res. 1999:59:5863-70.

6. Murphy BJ, Laderoute KR, Chin RJ, Sutherland RM. Metallothionein IIA is upregulated by hypoxia in human $\mathrm{A} 431$ squamous carcinoma cells. Cancer Res. 1994;54:5808-10.

7. Liu Y, Gao F, Song W. Periostin contributes to arsenic trioxide resistance in hepatocellular carcinoma cells under hypoxia. Biomed Pharmacother. 2017; 88:342-8.

8. Zhou Z, Fu XD. Regulation of splicing by SR proteins and SR protein-specific kinases. Chromosoma. 2013;122:191-207.

9. Pan Q, Shai O, Lee LJ, Frey BJ, Blencowe BJ. Deep surveying of alternative splicing complexity in the human transcriptome by high-throughput sequencing. Nat Genet. 2008:40:1413-5.

10. Biamonti G, Bonomi S, Gallo S, Ghigna C. Making alternative splicing decisions during epithelial-to-mesenchymal transition (EMT). Cell Mol Life Sci. 2012;69:2515-26.

11. Hang X, Li P, Li Z, Qu W, Yu Y, Li H, et al. Transcription and splicing regulation in human umbilical vein endothelial cells under hypoxic stress conditions by exon array. BMC Genomics. 2009;10:126.

12. Weigand JE, Boeckel JN, Gellert P, Dimmeler S. Hypoxia-induced alternative splicing in endothelial cells. PLoS One. 2012;7:e42697.

13. Yao Y, Shang J, Song W, Deng Q, Liu H, Zhou Y. Global profiling of the gene expression and alternative splicing events during hypoxia-regulated chondrogenic differentiation in human cartilage endplate-derived stem cells. Genomics. 2016;107:170-7.

14. Sena JA, Wang L, Heasley LE, Hu CJ. Hypoxia regulates alternative splicing of HIF and non-HIF target genes. Mol Cancer Res. 2014;12:1233-43.

15. Han J, Li J, Ho JC, Chia GS, Kato H, Jha S, et al. Hypoxia is a key driver of alternative splicing in human breast cancer cells. Sci Rep. 2017:7:4108.

16. Kemmerer K, Weigand JE. Hypoxia reduces MAX expression in endothelial cells by unproductive splicing. FEBS Lett. 2014;588:4784-90.

17. Bebee TW, Dominguez CE, Samadzadeh-Tarighat S, Akehurst KL, Chandler DS. Hypoxia is a modifier of SMN2 splicing and disease severity in a severe SMA mouse model. Hum Mol Genet. 2012;21:4301-13.

18. Venables JP, Koh CS, Froehlich U, Lapointe $E$, Couture $S$, Inkel $L$, et al. Multiple and specific mRNA processing targets for the major human hnRNP proteins. Mol Cell Biol. 2008;28:6033-43.

19. Klinck R, Bramard A, Inkel L, Dufresne-Martin G, Gervais-Bird J, Madden R, et al. Multiple alternative splicing markers for ovarian cancer. Cancer Res. 2008:68:657-63.

20. Schödel J, Oikonomopoulos S, Ragoussis J, Pugh CW, Ratcliffe PJ, Mole DR. High-resolution genome-wide mapping of HIF-binding sites by ChIP-seq. Blood. 2011;117:e207-17.

21. Loncaster JA, Harris AL, Davidson SE, Logue JP, Hunter RD, Wycoff CC, et al. Carbonic anhydrase (CA IX) expression, a potential new intrinsic marker of 
hypoxia: correlations with tumor oxygen measurements and prognosis in locally advanced carcinoma of the cervix. Cancer Res. 2001;61:6394-9.

22. Karni R, de Stanchina E, Lowe SW, Sinha R, Mu D, Krainer AR. The gene encoding the splicing factor SF2/ASF is a proto-oncogene. Nat Struct Mol Biol. 2007;14:185-93.

23. Jakubauskiene E, Vilys L, Makino Y, Poellinger L, Kanopka A. Increased serinearginine (SR) protein phosphorylation changes pre-mRNA splicing in hypoxia. J Biol Chem. 2015;290:18079-89.

24. Zahler AM, Neugebauer KM, Stolk JA, Roth MB. Human SR proteins and isolation of a cDNA encoding SRp75. Mol Cell Biol. 1993;13:4023-8.

25. Nayler O, Stamm S, Ullrich A. Characterization and comparison of four serine- and arginine-rich (SR) protein kinases. Biochem J. 1997;326:693-700.

26. Keshwani MM, Hailey KL, Aubol BE, Fattet L, McGlone ML, Jennings PA, Adams JA. Nuclear protein kinase CLK1 uses a non-traditional docking mechanism to select physiological substrates. Biochem J. 2015:472:329-38.

27. Starmans MH, Chu KC, Haider S, Nguyen F, Seigneuric R, Magagnin MG, et al. The prognostic value of temporal in vitro and in vivo derived hypoxia geneexpression signatures in breast cancer. Radiother Oncol. 2012;102:436-43.

28. Sakuma M, lida K, Hagiwara M. Deciphering targeting rules of splicing modulator compounds: case of TG003. BMC Mol Biol. 2015;16:16.

29. Memon D, Dawson K, Smowton CSF, Xing W, Dive C, Miller CJ. Hypoxiadriven splicing into noncoding isoforms regulates the DNA damage response. NPJ Genom Med. 2016;1:16020.

30. Dong Z, Wang JZ, Yu F, Venkatachalam M. Apoptosis-resistance of hypoxic cells. Am J Pathol. 2003;163:663-71.

31. Gortat A, Sancho M, Mondragón L, Messeguer À, Pérez-Payá E, Orzáez M. Apaf1 inhibition promotes cell recovery from apoptosis. Protein Cell. 2015;6:833-43.

32. Bao Q, Lu W, Rabinowitz JD, Shi Y. Calcium blocks formation of apoptosome by preventing nucleotide exchange in Apaf-1. Mol Cell. 2007:25:181-92

33. Benedict MA, Hu Y, Inohara N, Núñez G. Expression and functional analysis of Apaf-1 isoforms. Extra WD-40 repeat is required for cytochrome $\mathrm{c}$ binding and regulated activation of procaspase-9. J Biol Chem. 2000;275:8461-8.

34. Eisenreich A, Zakrzewicz A, Huber K, Thierbach H, Pepke W, Goldin-Lang P, et al. Regulation of pro-angiogenic tissue factor expression in hypoxiainduced human lung cancer cells. Oncol Rep. 2013:30:462-70.

35. Zu M, Li C, Fang JS, Lian WW, Liu AL, Zheng LS, et al. Drug discovery of host CLK1 inhibitors for influenza treatment. Molecules. 2015;20:19735-47.

36. Wong R, Balachandran A, Mao AYQ, Dobson W, Gray-Owen S, Cochrane A. Differential effect of CLK SR kinases on HIV-1 gene expression: potential novel targets for therapy. Retrovirology. 2011;8:47-59.

37. Murar M, Dobias J, Sramel P, Addova G, Hanquet G, Bohac A. Novel CLK1 inhibitors based on $\mathrm{N}$-aryloxazol-2-amine skeleton - a possible way to dual VEGFR2 TK/CLK ligands. Eur J Med Chem. 2017;126:754-61.

38. ElHady AK, Abdel-Halim M, Abadi AH, Engel M. Development of selective Clk1 and -4 inhibitors for cellular depletion of cancer-relevant proteins. J Med Chem. 2017:60:5377-91.

39. Rhodes DA, Stammers M, Malcherek G, Beck S, Trowsdale J. The cluster of BTN genes in the extended major histocompatibility complex. Genomics. 2001;71:351-62

40. Kano M, Matsushita K, Rahmutulla B, Yamada S, Shimada H, Kubo S, et al. Adenovirus-mediated FIR demonstrated TP53-independent cell-killing effect and enhanced antitumor activity of carbon-ion beams. Gene Ther. 2015;23:50-6.

41. Matsushita K, Kitamura K, Rahmutulla B, Tanaka N, Ishige T, Satoh M, et al. Haploinsufficiency of the c-myc transcriptional repressor FIR, as a dominant negative-alternative splicing model, promoted p53-dependent T-cell acute lymphoblastic leukemia progression by activating Notch1. Oncotarget. 2015;6:5102.

42. Hauser AD, Bergom C, Schuld NJ, Chen X, Lorimer EL, Huang J, et al. The SmgGDS splice variant SmgGDS-558 is a key promoter of tumor growth and RhoA signaling in breast cancer. Mol Cancer Res. 2014;12:130-42.

43. Rajgor D, Mellad JA, Autore F, Zhang Q, Shanahan CM. Multiple novel nesprin-1 and nesprin-2 variants act as versatile tissue-specific intracellular scaffolds. PLoS One. 2012;7:e40098.

\section{Submit your next manuscript to BioMed Central and we will help you at every step:}

- We accept pre-submission inquiries

- Our selector tool helps you to find the most relevant journal

- We provide round the clock customer support

- Convenient online submission

- Thorough peer review

- Inclusion in PubMed and all major indexing services

- Maximum visibility for your research

Submit your manuscript at www.biomedcentral.com/submit

Biomed Central 